\title{
Ischemic colitis during pegylated interferon-alpha and ribavirin therapy for chronic hepatitis $\mathrm{C}$
}

\author{
Yvette Leung $M D^{1}$, Stefan J Urbanski MD², Lynn Schindel RN¹, Robert P Myers MD ${ }^{1}$
}

Y Leung, SJ Urbanski, L Schindel, RP Myers. Ischemic colitis during pegylated interferon-alpha and ribavirin therapy for chronic hepatitis C. Can J Gastroenterol 2006;20(10):661-663.

Rare cases of ischemic colitis associated with interferon-alpha (IFN- $\alpha$ ) treatment for chronic hepatitis $\mathrm{C}(\mathrm{HCV})$ infection and metastatic cancer have been reported. The present study describes the first case of ischemic colitis attributable to pegylated IFN- $\alpha$ and ribavirin combination therapy in an HCV-infected patient after 34 weeks of treatment. The clinical presentation, endoscopic appearance and histopathology of the colon were consistent with ischemic colitis, and the patient's symptoms rapidly resolved with cessation of therapy. The association between the therapy and the pathogenesis of ischemic colitis is unclear, but immunoregulatory, vasospastic and procoagulant mechanisms have been proposed. Physicians should be aware of this complication, and should consider it in any HCVinfected patient taking pegylated IFN- $\alpha$ and ribavirin who develops abdominal discomfort and gastrointestinal bleeding.

Key Words: Adverse effects; Colitis; Drug toxicity; Hepatitis C; Interferon; Ischemia; Pegylated interferon-alpha; Ribavirin

Interferons (IFNs) developed by cell culture or recombinant technology have been available for the treatment of hepatitis $\mathrm{C}$ virus (HCV) infection since the early 1990s (1). IFN- $\alpha$ acts in vivo to inhibit de novo infection of susceptible cells and to block virion production and release $(2,3)$.

Combination therapy with pegylated (Peg) IFN- $\alpha$ and ribavirin (RBV) leads to a sustained virological response in $42 \%$ to $52 \%$ of patients with genotype $1 \mathrm{HCV}$ infection (4-6).

Common adverse events include influenza-like symptoms, insomnia, irritability and depression. Gastrointestinal symptoms, including nausea, vomiting, anorexia and diarrhea, affect approximately one-third of patients (7). Precipitation or exacerbation of underlying inflammatory bowel disease $(8,9)$ and ischemic colitis (with IFN monotherapy) $(10,11)$ have rarely been reported. In the present report, we describe the first case of ischemic colitis associated with PegIFN- $\alpha-2 \mathrm{a}$ and RBV combination therapy, with the intention of highlighting this potential complication of antiviral treatment.

\section{CASE PRESENTATION}

A 44-year-old Caucasian man presented with a one-day history of acute, left lower quadrant abdominal pain and bloody diarrhea. The patient was on his 34th week of PegIFN- $\alpha-2 \mathrm{a}$ (Pegasys $180 \mu g$ weekly, Hoffmann-La Roche, Canada) and

\section{Colite ischémique et traitement de l'hépatite C à l'interféron alpha pégylé et à la ribavirine}

La documentation médicale ne fait état que de rares cas de colite ischémique associée à l'administration d'interféron alpha (INF $\alpha$ ) pour le traitement de l'hépatite $\mathrm{C}$ chronique ou de cancers métastatiques. Suit la description d'un premier cas de colite ischémique attribuable à l'association de l'INF $\alpha$ pégylé et de la ribavirine après 34 semaines de traitement chez un patient atteint d'hépatite $\mathrm{C}$ chronique. Le tableau clinique, l'apparence à l'examen endoscopique et l'examen histopathologique du côlon étaient compatibles avec ceux de la colite ischémique, et les symptômes sont disparus rapidement après l'arrêt du traitement. On ne comprend pas très bien les liens entre le traitement et la pathogenèse de la colite ischémique, mais on croit que des mécanismes immunorégulateurs, angiospastiques et propices à la coagulation pourraient être en cause. Les médecins devraient être sensibilisés à la complication et devraient l'envisager chez les patients atteints d'hépatite $\mathrm{C}$, traités à l'INF $\alpha$ pégylé et à la ribavirine, qui se plaignent de malaises abdominaux et qui présentent des hémorragies digestives.

${ }^{1}$ Liver Unit, Division of Gastroenterology, Department of Medicine; ${ }^{2}$ Department of Pathology, University of Calgary, Calgary, Alberta

Correspondence: Dr Robert P Myers, Viral Hepatitis Clinic, G126-3330 Hospital Drive North West, Calgary, Alberta T2N 4 N1.

Telephone 403-210-9837, fax 403-210-9368, e-mail rpmyers@ucalgary.ca

Received for publication October 7, 2005. Accepted January 16, 2006 


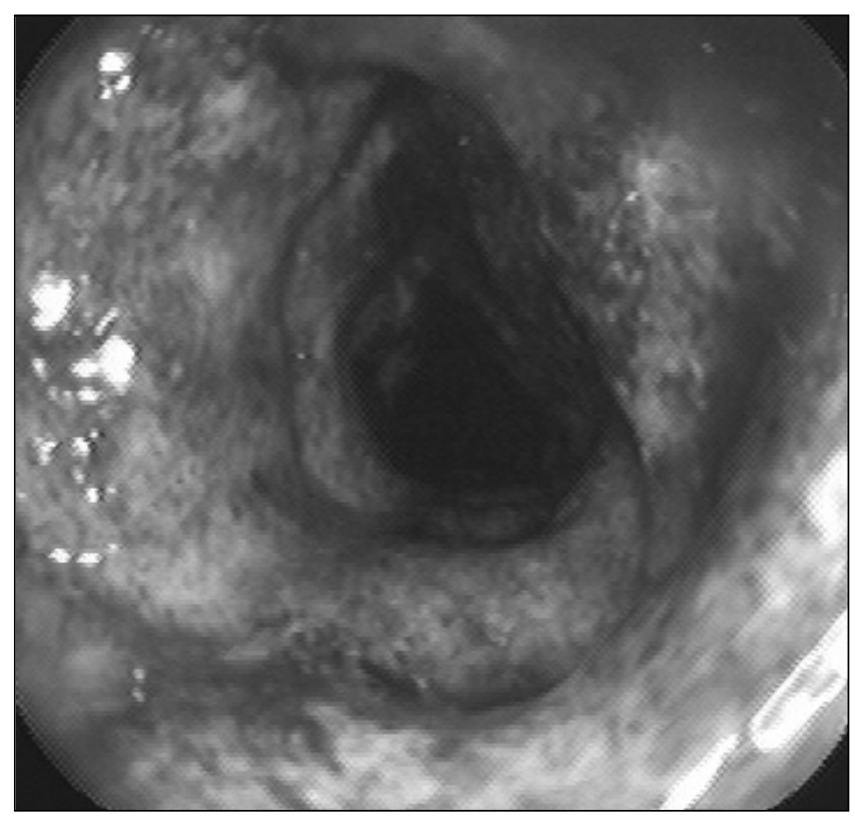

Figure 1) Endoscopic image from the left colon demonstrating mucosal ulceration, hemorrhage, edema and friability consistent with ischemic colitis

tenderness with voluntary guarding and rebound tenderness. A rectal examination revealed bright red blood and external hemorrhoids. Laboratory investigations demonstrated normocytic anemia (hemoglobin level of $97 \mathrm{~g} / \mathrm{L}$; normal values $137 \mathrm{~g} / \mathrm{L}$ to $180 \mathrm{~g} / \mathrm{L}$ ), leukopenia (white blood cell count of $3.7 \times 10^{9} / \mathrm{L}$; normal values $4 \times 10^{9} / \mathrm{L}$ to $11 \times 10^{9} / \mathrm{L}$ ) and thrombocytopenia (platelet count of $103 \times 10^{9} / \mathrm{L}$; normal values $150 \times 10^{9} / \mathrm{L}$ to $400 \times 10^{9} / \mathrm{L}$ ), all attributed to antiviral therapy. Serum electrolyte, creatinine, liver biochemistry, lipase, coagulation profile and venous lactate values were within normal limits. Abdominal radiographs were unremarkable. Flexible sigmoidoscopy demonstrated severe inflammation in the left colon from the sigmoid to the splenic flexure, typical of ischemic colitis (Figure 1). Biopsies revealed superficial loss of the epithelial lining with crypt destruction, congestion and hemorrhage, consistent with ischemic damage (Figure 2) (13). Stool cultures were negative.

A diagnosis of ischemic colitis, possibly related to PegIFN- $\alpha-2 a$ and RBV therapy, was made. Antiviral therapy was discontinued, and the patient's symptoms resolved within three days. The patient did not resume anti-HCV therapy and remains well over six months following initial presentation. His liver biochemistry remains normal and HCV RNA negative, indicative of a sustained virological response despite the truncated course of therapy.

\section{DISCUSSION}

Ischemic colitis has been reported in association with a variety of medications (eg, oral contraceptives, vasoconstrictors and 5-hydroxytryptamine agonists/antagonists) and illicit drugs (eg, cocaine and methamphetamine) $(14,15)$. Tada et al (10) and Okanoue et al (11) reported two cases of ischemic colitis in HCV-infected patients receiving high-dose IFN- $\alpha$ monotherapy $(10,11)$. To our knowledge, the patient described is the first case of ischemic colitis attributable to PegIFN- $\alpha$ and RBV combination therapy.

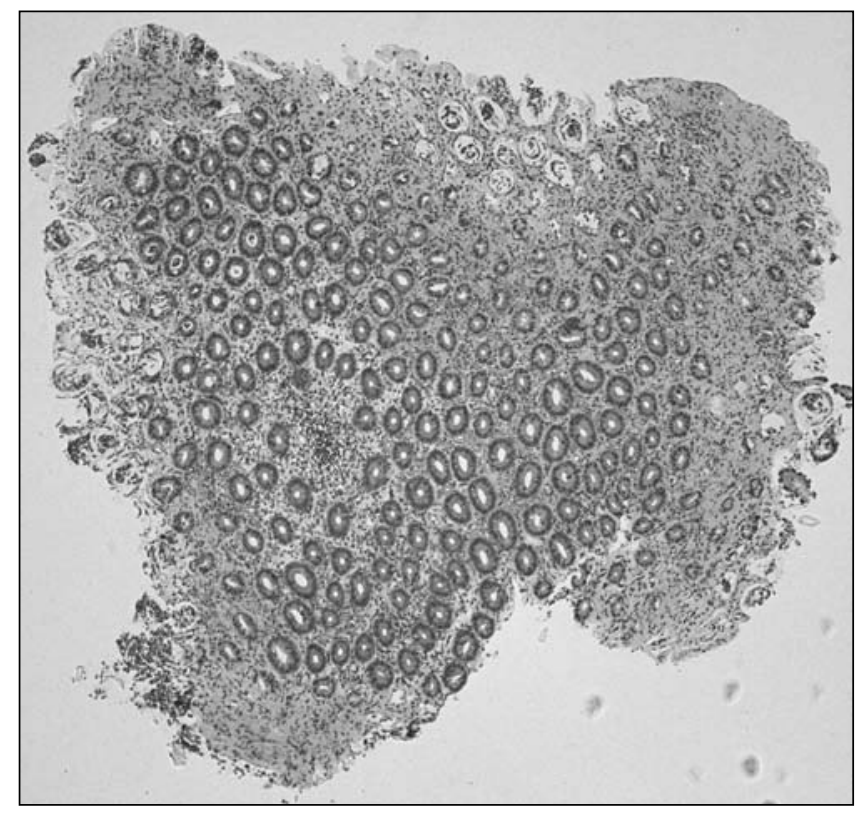

Figure 2) Colonic biopsies demonstrating loss of surface epithelium and upper portions of the crypts with homogenization of the superficial portion of the lamina propria, consistent with ischemic damage. Hematoxylin and eosin stain, original magnification $\times 40$

Similar to the patients described by Tada et al (10) and Okanoue et al (11), as well as most patients with ischemic colitis, our patient did not have any conditions that were predisposed to colonic ischemia, such as known atherosclerosis, vasculitides (including $\mathrm{HCV}$-associated cryoglobulinemic vasculitis), thrombophilias or use of vasopressive medications $(14,15)$.

We are confident that a causal relationship exists between PegIFN $-\alpha$ and RBV therapy and ischemic colitis in our patient. The temporal relationship, specifically, the rapid resolution following cessation of therapy, is supportive. Although a remote cocaine abuser, he denied recent use. Unfortunately, drug screening was not performed to exclude recidivism. An additional confounding factor in establishing causation in this patient was his daily use of cannabis. Although cannabis has not been reported to cause ischemic colitis, it has been implicated in cases of stroke $(16,17)$, transient ischemic attack (18), paroxysmal atrial fibrillation (19) and sudden cardiac death (20). Moreover, cannabis increases the risk of myocardial infarction 4.8-fold within $1 \mathrm{~h}$ following its intake (21). Vasospasm $(16,17)$ and/or an arteritis similar to Buerger's disease (22) have been proposed as potential mechanisms. Although impossible to prove, the patient's long-standing use of cannabis without previous ischemic complications and development of recurrent ischemic colitis with ongoing use argue against this being the causative agent in this case. However, cannabis (and cigarette) smoking may have predisposed the patient to ischemic colitis, induced by PegIFN- $\alpha /$ RBV therapy.

Assuming ischemic colitis in our patient was attributable to combination antiviral therapy, determining the offending agent is difficult. While hemolytic anemia attributable to RBV may have contributed to impaired colonic oxygenation (23), RBV has not been reported to be a cause of ischemic colitis. We speculate that PegIFN- $\alpha$ was the major factor, particularly in light of previous reports of an association with other 
ischemic events, including anterior optic neuropathy (24), Raynaud's syndrome (25), coronary vasospasm (26), and cardiac arrhythmias and myocardial infarction (27), in IFN- $\alpha$-treated patients. Ischemic colitis has not been reported with other Peg proteins (eg, pegvisomant, pegfilgrastim or pegademase) (28), suggesting that the inert, polyethylene glycol moiety of PegIFN- $\alpha$ is unlikely to be the causative agent.

To our knowledge, the molecular mechanisms underlying PegIFN- $\alpha$-associated ischemic colitis have not been established. Sparano et al (29) reported an association between ischemic colitis and IFN- $\alpha$ when used in combination with high-dose interleukin-2 (IL-2) for the treatment of metastatic cancer. In this study, three of 21 patients (14\%) receiving IL-2 and IFN- $\alpha$ developed colonic ischemia, versus none of the 120 patients treated with IL-2 alone $(\mathrm{P}=0.003)$. They postulated that IL-2 therapy produces increased levels of tumour necrosis factor and IFN- $\gamma$, triggering coagulation and deposition of fibrin thrombi, as part of the pathogenesis of colonic ischemia (29). A potentiating role of IFN- $\alpha$ could be explained by its propensity to stimulate $\mathrm{T}$ helper 1 cells to produce IL-2 and IFN- $\gamma$ (30). In the absence of concomitant

\section{REFERENCES}

1. Davis GL. Treatment of chronic hepatitis C. BMJ 2001;323:1141-2.

2. Neumann AU, Lam NP, Dahari H, et al. Hepatitis $\mathrm{C}$ viral dynamics in vivo and the antiviral efficacy of interferon-alpha therapy. Science 1998;282:103-7.

3. Zeuzem S, Schmidt JM, Lee JH, Ruster B, Roth WK. Effect of interferon alfa on the dynamics of hepatitis $\mathrm{C}$ virus turnover in vivo. Hepatology 1996;23:366-71.

4. Fried MW, Shiffman ML, Reddy KR, et al. Peginterferon alfa-2a plus ribavirin for chronic hepatitis $\mathrm{C}$ virus infection. $\mathrm{N}$ Engl J Med 2002;347:975-82.

5. Hadziyannis SJ, Sette H Jr, Morgan TR, et al. Peginterferon-alpha2a and ribavirin combination therapy in chronic hepatitis $\mathrm{C}$ :

A randomized study of treatment duration and ribavirin dose. Ann Intern Med 2004;140:346-55.

6. Manns MP, McHutchison JG, Gordon SC, et al. Peginterferon alfa- $2 \mathrm{~b}$ plus ribavirin compared with interferon alfa- $2 \mathrm{~b}$ plus ribavirin for initial treatment of chronic hepatitis C: A randomised trial. Lancet 2001;358:958-65.

7. Russo MW, Fried MW. Side effects of therapy for chronic hepatitis C. Gastroenterology 2003;124:1711-9.

8. Sprenger R, Sagmeister M, Offner F. Acute ulcerative colitis during successful interferon/ribavirin treatment for chronic hepatitis. Gut 2005;54:438-9.

9. Mavrogiannis C, Papanikolaou IS, Elefsiniotis IS, Psilopoulos DI, Karameris A, Karvountzis G. Ulcerative colitis associated with interferon treatment for chronic hepatitis C. J Hepatol 2001;34:964-5.

10. Tada H, Saitoh S, Nakagawa Y, et al. Ischemic colitis during interferon-alpha treatment for chronic active hepatitis $\mathrm{C}$. J Gastroenterol 1996;31:582-4.

11. Okanoue T, Sakamoto S, Itoh Y, et al. Side effects of high-dose interferon therapy for chronic hepatitis C. J Hepatol 1996;25:283-91.

12. Intraobserver and interobserver variations in liver biopsy interpretation in patients with chronic hepatitis $\mathrm{C}$. The French METAVIR Cooperative Study Group. Hepatology 1994;20:15-20.

13. Mitsudo S, Brandt LJ. Pathology of intestinal ischemia. Surg Clin North Am 1992;72:43-63.

14. Burns BJ, Brandt LJ. Intestinal ischemia. Gastroenterol Clin North Am 2003;32:1127-43.

15. Brandt LJ, Boley SJ. AGA technical review on intestinal ischemia. American Gastrointestinal Association. Gastroenterology 2000;118:954-68.

16. Mateo I, Pinedo A, Gomez-Beldarrain M, Basterretxea JM, Garcia-Monco JC. Recurrent stroke associated with cannabis use. J Neurol Neurosurg Psychiatry 2005;76:435-7.

17. Zachariah SB. Stroke after heavy marijuana smoking. Stroke 1991;22:406-9.
IL-2 therapy, several mechanisms for IFN-induced vascular pathology have been proposed including:

- a direct vasospastic effect (31);

- a procoagulant effect promoting multifocal, arterial thrombotic occlusions (32);

- drug-induced acceleration of lymphocyte attachment to endothelial cells (33); and

- deposition of immune complexes and vasculitis (34). Clearly, additional study of the molecular mechanisms behind IFN-induced ischemia is warranted.

\section{CONCLUSION}

PegIFN- $\alpha$ in combination with RBV is a highly effective treatment for chronic HCV infection. Although rare, ischemic colitis is a potential adverse effect of this therapy. Physicians in all areas of practice should be aware of this complication, and should consider it in any patient taking PegIFN- $\alpha$ and RBV who develops abdominal discomfort and gastrointestinal bleeding.

18. Lawson TM, Rees A. Stroke and transient ischemic attacks in association with substance abuse in a young man. Postgrad Med J 1996;72:692-3.

19. Kosior DA, Filipiak KJ, Stolarz P, Opolski G. Paroxysmal atrial fibrillation following marijuana intoxication: A two-case report of possible association. Int J Cardiol 2001;78:183-4.

20. Bachs L, Morland H. Acute cardiovascular fatalities following cannabis use. Forensic Sci Int 2001;124:200-3.

21. Mittleman MA, Lewis RA, Maclure M, Sherwood JB, Muller JE. Triggering myocardial infarction by marijuana. Circulation 2001;103:2805-9.

22. Disdier P, Granel B, Serratrice J, et al. Cannabis arteritis revisited - ten new case reports. Angiology 2001;52:1-5.

23. Sulkowski MS, Wasserman R, Brooks L, Ball L, Gish R. Changes in haemoglobin during interferon alpha-2b plus ribavirin combination therapy for chronic hepatitis $\mathrm{C}$ virus infection. J Viral Hepat 2004;11:243-50.

24. Purvin VA. Anterior ischemic optic neuropathy secondary to interferon alfa. Arch Ophthalmol 1995;113:1041-4.

25. Schapira D, Nahir AM, Hadad N. Interferon-induced Raynaud's syndrome. Semin Arthritis Rheum 2002;32:157-62.

26. Tanaka H, Yamakado T, Emi Y, Nabeshima K, Itoh S, Nakano T. Interferon-induced coronary vasospasm. A case history. Angiology 1995;46:1139-43.

27. Sonnenblick M, Rosin A. Cardiotoxicity of interferon. A review of 44 cases. Chest 1991;99:557-61.

28. Molineux G. Pegylation: Engineering improved biopharmaceuticals for oncology. Pharmacotherapy 2003;23:3S-8S.

29. Sparano JA, Dutcher JP, Kaleya R, et al. Colonic ischemia complicating immunotherapy with interleukin-2 and interferon-alpha. Cancer 1991;68:1538-44.

30. Tilg H. New insights into the mechanisms of interferon alfa: An immunoregulatory and anti-inflammatory cytokine. Gastroenterology 1997;112:1017-21.

31. Zeidman A, Dicker D, Mittelman M. Interferon-induced vasospasm in chronic myeloid leukaemia. Acta Haematol 1998;100:94-6.

32. Cnudde F, Gharakhanian S, Luboinski J, Dry J, Rozenbaum W. Cutaneous local necrosis following interferon injections. Int J Dermatol 1991;30:147.

33. Blaheta RA, Scholz M, Hailer NP, Bereiter-Hahn J, Encke A, Markus BH. Adhesion and penetration properties of human lymphocytes acting on allogeneic vascular endothelial cells. Immunology 1994;81:538-45.

34. Ronnblom LE, Alm GV, Oberg K. Autoimmune phenomena in patients with malignant carcinoid tumors during interferon-alpha treatment. Acta Oncol 1991;30:537-40. 


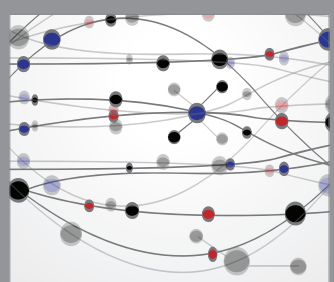

The Scientific World Journal
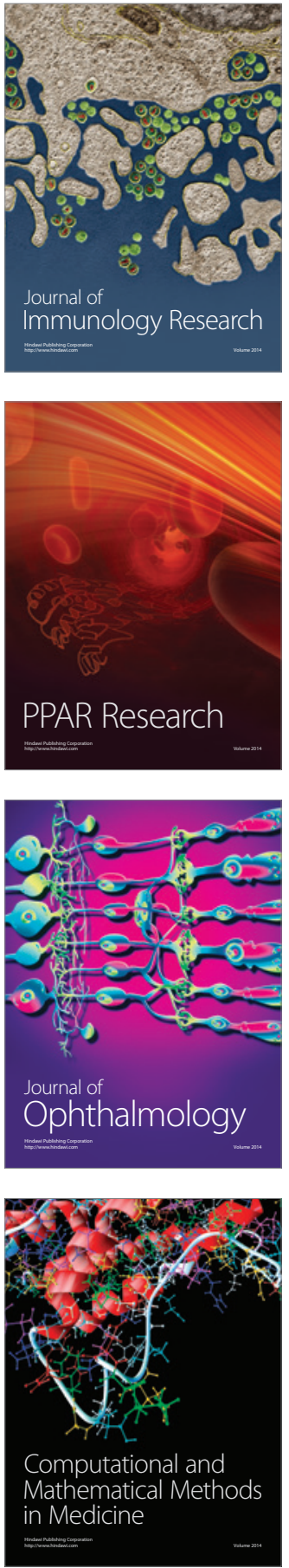

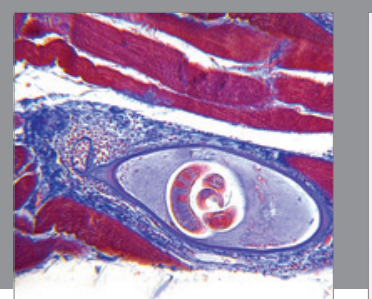

Gastroenterology Research and Practice

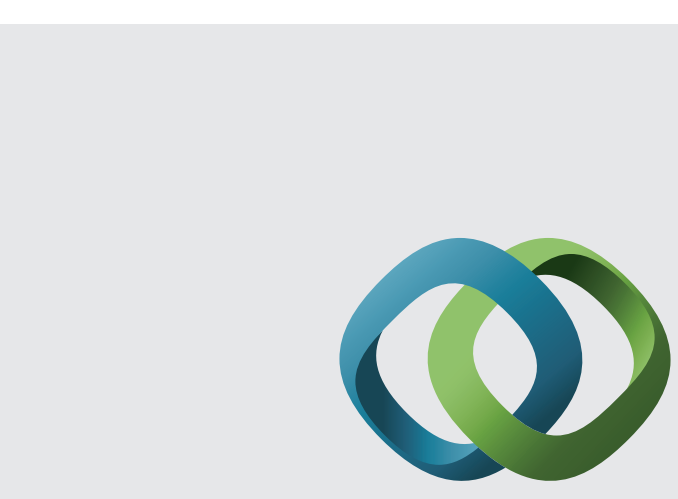

\section{Hindawi}

Submit your manuscripts at

http://www.hindawi.com
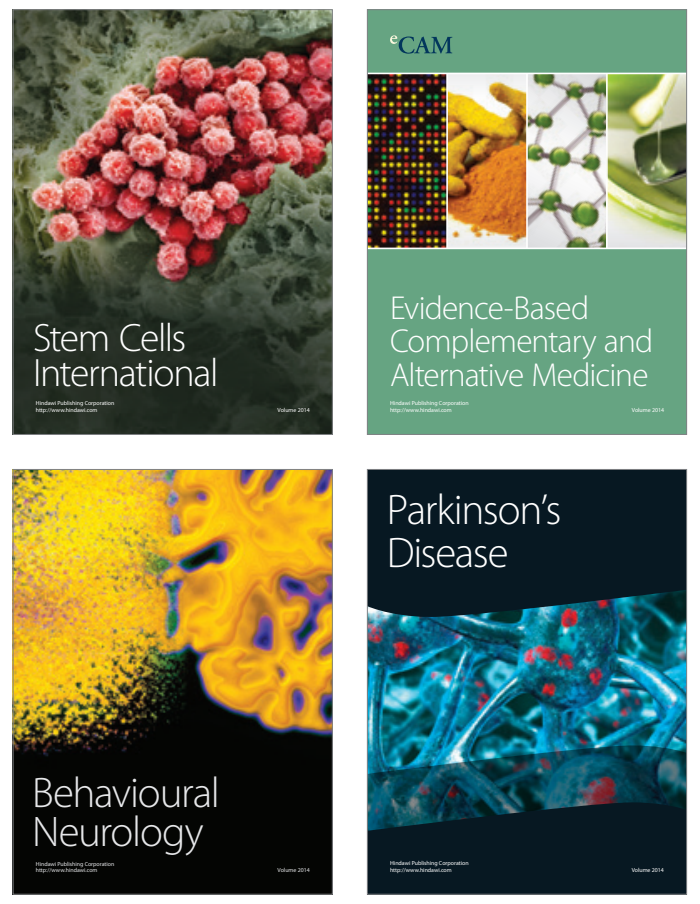
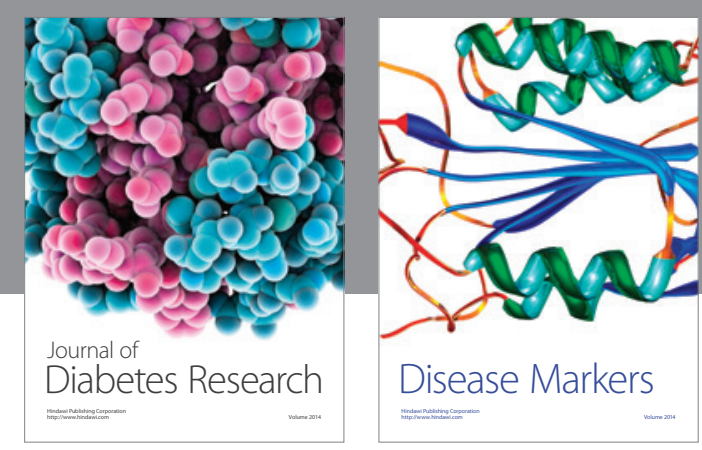

Disease Markers
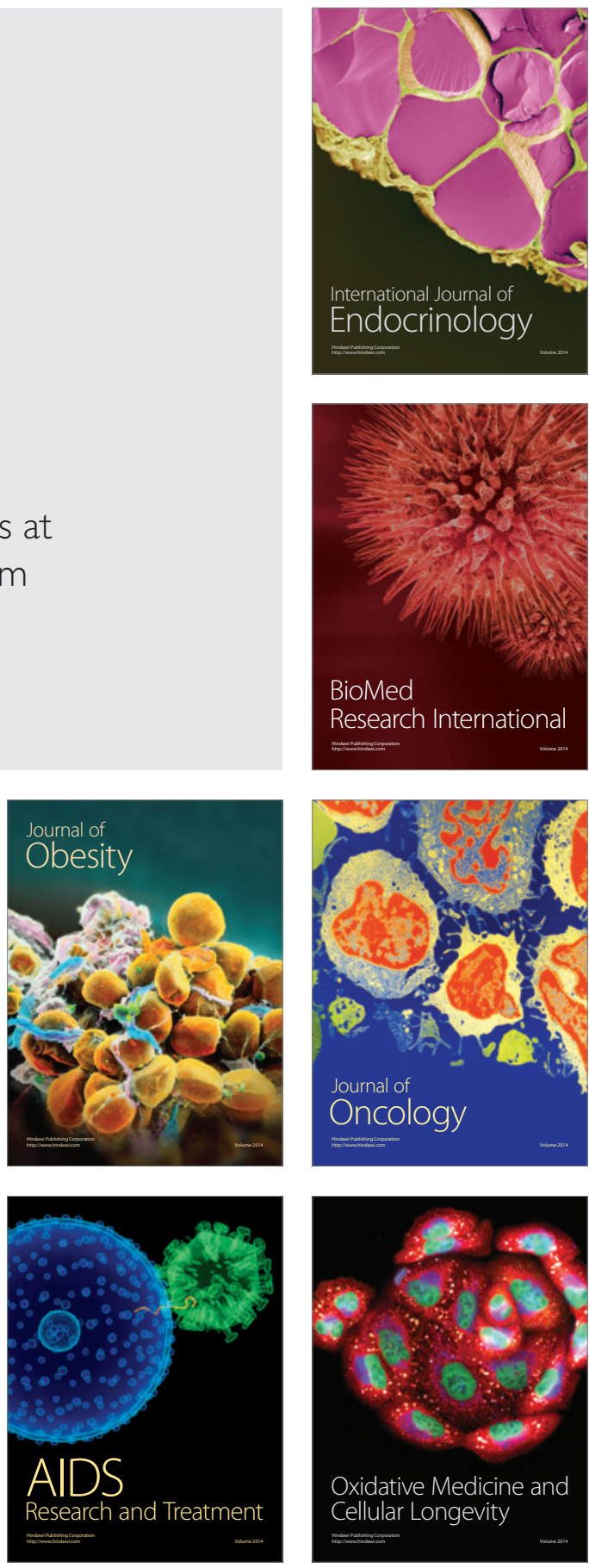